\title{
Synthesis of Cellulase by Mucor pusillus and Mucor mienet
}

\author{
By G. A. SOMKUTI \\ Department of Biological Sciences, Purdue University, \\ West Lafayette, Indiana 47907, U.S.A.
}

(Received 6 March 1973; revised 20 September 1973)

\begin{abstract}
SUMMARY
Strains of Mucor pusillus and M. miehei were found to synthesize $\beta$-I,4-glucan glucanohydrolase (cellulase) in a complex medium. The inducible enzyme complex hydrolysed carboxymethylcellulose, acid-swollen cellulose and unmodified cellulose.
\end{abstract}

\section{INTRODUCTION}

Several investigators have reported that thermophilic species of Mucor are non-cellulolytic (Chang, 1967; Rész, 1968; Eggins \& Malik, 1969; Fergus, 1969; Tansey, 197I). On the other hand, Mucor pusillus was reported to produce cellulase ( $\beta$-I,4-glucan glucanohydrolase, EC. 3.2.I.4) by Somkuti, Babel \& Somkuti (1969). However, the culture used by Somkuti et al. was subsequently identified as $M$. miehei by J. J. Ellis (Department of Agriculture, Peoria, Illinois, U.S.A.). In view of this development and the persistence of negative data in recent literature concerning the cellulolytic ability of thermophilic Mucor fungi (Tansey, 197I) we have re-examined previous findings, extending the investigation to include several strains of $M$. pusillus and $M$. miehei.

\section{METHODS}

Cultures and culture maintenance. Mucor pusillus Cooney \& Emerson, strains 6 and 8, were obtained from D. J. Cooney (University of Nevada). Mucor pusillus PCC4 10 originated from the Purdue University Culture Collection and its identity was verified by D. J. Cooney (personal communication). Mucor miehei Cooney \& Emerson was a gift from D. J. Cooney; Mucor miehei NRRL2543 and NRRL3I69 were obtained from J. J. Ellis. Stock cultures were propagated on $10 \%(\mathrm{w} / \mathrm{v})$ potato malt agar (Difco) slants at $37{ }^{\circ} \mathrm{C}$ and transferred weekly.

Production of cellulase. A $4 \%(\mathrm{w} / \mathrm{v})$ wheat-bran suspension in deionized water was kept at boiling point for $30 \mathrm{~min}$. The suspension was filtered through gauze, dispensed in I 1 Erlenmeyer flasks ( $300 \mathrm{ml} /$ flask), and autoclaved at I2 I ${ }^{\circ} \mathrm{C}$ for $20 \mathrm{~min}$. The $\mathrm{pH}$ before autoclaving was 6.8 and was not adjusted. Inoculum was prepared by flooding agar slants, each with $10 \mathrm{ml}$ of sterile deionized water. Incubation was on a gyrotory shaker at $37{ }^{\circ} \mathrm{C}$ for 7 days. The flasks were cooled to $4{ }^{\circ} \mathrm{C}$ and the broth was filtered through four layers of sterile gauze into pre-chilled vessels. The filtrates were centrifuged at $10000 \mathrm{~g}$ at $4{ }^{\circ} \mathrm{C}$ for $20 \mathrm{~min}$. The supernatants served as the crude cellulase preparations and were used immediately.

Assay of cellulase and $\beta$-glucosidase activity. Protein content of the various enzyme preparations was measured by the method of Lowry, Rosebrough, Farr \& Randall (I95I) with bovine serum albumin as the standard. In the determination of cellulase activity, the 
following carboxymethylcellulose (CMC) preparations, each with a different degree of substitution (d.s.) and/or viscosity range (v.r.), were employed: $\mathrm{CMC} 4 \mathrm{HIF}$ (d.s. 0.4 , v.r. high), CMC $7 \mathrm{LF}$ (d.s. 0.7, v.r. low), CMC $7 \mathrm{MF}$ (d.s. 0·7, v.r. medium), CMC $7 \mathrm{HF}$ (d.s. 0.7 , v.r. high), CMC 9M8F (d.s. 0.9, v.r. medium), and CMC I2M8P (d.s. I.2, v.r., medium). All CMC preparations were obtained from Hercules Inc., Oak Brook, Illinois, U.S.A. Stock solutions of substrates $(0.25 \%, \mathrm{w} / \mathrm{v})$ were prepared in $0.1 \mathrm{M}$-sodium acetate buffer, $\mathrm{pH} 5.0$. In the enzyme assays, $0.5 \mathrm{ml}$ enzyme was mixed with $\mathrm{I} \cdot 5 \mathrm{ml}$ substrate and incubated at $37^{\circ} \mathrm{C}$. The amount of reducing sugar produced from $\mathrm{CMC}$ was calculated as glucose according to a modification of Bernfeld's method (1955). One unit of enzyme activity was defined as the amount of reducing sugar, in $\mu$ mol, liberated by I $\mathrm{mg}$ of enzyme protein $/ \mathrm{h}$ at $37^{\circ} \mathrm{C}$.

In the assay of $\beta$-glucosidase activity, $p$-nitrophenyl- $\beta$-D-glycopyranoside (PNPG, Sigma Chemical Co., St Louis, Missouri, U.S.A.) was used. One $\mathrm{ml}$ of a $10^{-4} \mathrm{M}-\mathrm{PNPG}$ stock solution prepared in $0^{\circ} \mathrm{I}$ M-sodium acetate $\left(\mathrm{pH}_{5}{ }^{\circ} \mathrm{O}\right)$ was mixed with $\mathrm{I}$ ml crude enzyme solution and incubated for $\mathrm{I} \mathrm{h}$ at $30^{\circ} \mathrm{C}$. The reaction was stopped by adding $2 \mathrm{ml}$ of I $\mathrm{M}-\mathrm{Na}_{2} \mathrm{CO}_{3}$ solution. Absorbance was read at $400 \mathrm{~nm}$ in a Beckman DU spectrophotometer. One unit of $\beta$-glucosidase activity was defined as the amount ( $\mu \mathrm{mol})$ of PNPG hydrolysed/h by I mg of enzyme protein.

Hydrolysis of acid-swollen cellulose, CMC, unmodified cellulose and cellobiose, and the identification of hydrolytic products. Acid-swollen cellulose was prepared according to the method of Walseth (I952). Other substrates were Whatman ashless cellulose powder (standard grade), $\mathrm{CMC} 4 \mathrm{HIF}$, and cellobiose. To Ioo $\mathrm{mg}$ of substrate (except for cellobiose, of which only Io $\mathrm{mg}$ were used) suspended in $8 \mathrm{ml}$ of $0^{\circ} \mathrm{I}$ M-acetate buffer ( $\mathrm{pH} 5^{\circ}$ ), were added $2 \mathrm{ml}$ of enzyme solution. The reaction mixture was covered with toluene and incubated at $37^{\circ} \mathrm{C}$ for varying lengths of time. The products of hydrolysis were identified by paper chromatography. Reaction mixtures were treated with MB-3 mixed-bed ionexchanger (Mallinckrodt) and filtered through Whatman no. 42 filter paper. The filtrates were evaporated to dryness under heat lamps. The residues were dissolved in deionized water and spotted on Whatman no. 4 chromatography paper. Paper chromatograms were developed in an isopropanol- $n$-butanol--water (I40:20:40, v/v) system at $25^{\circ} \mathrm{C}$ for I $6 \mathrm{~h}$. Carbohydrates were reacted with triphenyltetrazolium chloride or $\mathrm{AgNO}_{3}$ as described by Trevelyan, Procter \& Harrison (1950).

\section{RESULTS}

\section{Cellulase and $\beta$-glucosidase activity of Mucor pusillus and M. miehei}

The results of a time study indicated that all six strains had the capacity to hydrolyse CMC. The total amount of reducing sugar produced after $6 \mathrm{~h}$ of incubation ranged from 3 to $2 \mathrm{I} \mu \mathrm{mol}$, indicating a large degree of fluctuation in cellulase activity among the various strains of the two species cultivated under identical conditions. It was also evident that $\mathrm{I} h$ incubation time was long enough to measure the activity of even the least active preparation (Mucor miehei Cooney \& Emerson). The specific activity of each enzyme preparation was determined for a number of CMC preparations (Table I). A correlation was found between the activity of enzymes and the molecular organization of the substrates. As a rule, with increasing degree of substitution in the substrate the specific cellulase activity of the crude enzyme diminished. This was true for all enzyme preparations examined, which would indicate the likely presence of a $\beta$-I,4-glucan endo-hydrolase in the enzyme complex requiring the availability of adjacent unsubstituted anhydroglucose units for activity. There was also a clear, though less significant, negative correlation between the 
Table I. Specific activity of Mucor pusillus and M. miehei $\beta$-I,4-glucan glucanohydrolase with various carboxymethylcellulase preparations

\begin{tabular}{|c|c|c|c|c|c|c|}
\hline \multirow[b]{2}{*}{ Source of enzyme } & \multicolumn{6}{|c|}{$\begin{array}{l}\text { Glucose liberated from CMC by I mg of } \\
\text { enzyme protein } / \mathrm{h} \text { at } 37^{\circ} \mathrm{C}(\mu \mathrm{mol})\end{array}$} \\
\hline & $4 \mathrm{HIF}$ & $7 \mathrm{LF}$ & $7 \mathrm{MF}$ & $7 \mathrm{HF}$ & $9 \mathrm{M} 8 \mathrm{~F}$ & $12 \mathrm{M} 8 \mathrm{P}$ \\
\hline Mucor pusillus $\mathrm{PCC} 4 \mathrm{IO}$ & 4.05 & $2 \cdot 70$ & $2 \cdot 48$ & I 99 & $1 \cdot 48$ & $0 \cdot 70$ \\
\hline M. pusillus Cooney \& Emerson (strain 6) & $5 \cdot 60$ & $3 \cdot 94$ & $3 \cdot 40$ & $3 \cdot 15$ & $2 \cdot 02$ & $1 \cdot 10$ \\
\hline M. pusillus Cooney \& Emerson (strain 8) & $\mathrm{I} \cdot 80$ & $I \cdot 65$ & $1 \cdot 47$ & $1 \cdot 32$ & $\mathrm{I} \cdot 02$ & 0.63 \\
\hline M. miehei NRRL2543 & $2 \cdot 33$ & $2 \cdot 06$ & $I \cdot 92$ & $1 \cdot 65$ & $\mathrm{I} \cdot 37$ & 0.88 \\
\hline M. miehei NRRL3I 69 & 3.85 & $3 \cdot 85$ & $3 \cdot 08$ & $2 \cdot 88$ & $2 \cdot 14$ & $\mathrm{I} \cdot 32$ \\
\hline M. miehei Cooney \& Emerson & 0.70 & 0.64 & 0.58 & 0.50 & 0.44 & 0.35 \\
\hline
\end{tabular}

viscosity ranges of a particular substrate having the same degree of substitution, and cellulase activity. Apparently, the increased viscosity of the substrate presented a physical barrier to the formation of the enzyme-substrate complex.

The specific activity of $\beta$-glucosidase also varied among the cultures (from 0.23 to 0.62 enzyme units/mg protein) and there was no correlation between the respective specific activities of cellulase and $\beta$-glucosidase present in the same enzyme preparation.

\section{Paper chromatography of hydrolytic products}

A time study was carried out on the hydrolysis of carboxymethylcellulose (CMC $4 \mathrm{HIF})$ and cellobiose by crude enzyme preparations of Mucor pusillus Cooney \& Emerson (strain 6) and $M$. miehei NRRL2543. Reaction mixtures were incubated at $30^{\circ} \mathrm{C}$ and samples were taken for sugar analysis at pre-determined intervals. The chromatographic evidence clearly showed that both Mucor pusillus and Mucor miehei hydrolysed CMC to glucose. Also, as the incubation time increased, more slowly-moving components appeared on the chromatograms.

The $\beta$-glucosidase activity of crude enzyme preparations was examined with cellobiose as the substrate. The chromatograms indicated the almost complete hydrolysis of cellobiose to glucose. Transient products with low $R_{F}$ values were also observed, suggesting the presence of glycosyltransferase activity in the enzyme preparations. However, these transient products also appeared to be susceptible to hydrolytic attack by one or more components of the enzyme complex because they became nearly undetectable towards the end of incubation.

The hydrolysis of unmodified cellulose and acid-swollen cellulose by all six cultures was also examined! (Fig. I, 2) by using partially purified enzyme preparations devoid of $\beta$-glucosidase activity (Somkuti et al. 1969). Only glucose was present on chromatograms when unmodified cellulose served as the substrate, but both cellobiose and glucose were detected when the substrate was acid-swollen cellulose. Unmodified cellulose, because of its highly crystalline structure, may have been attacked by a $\beta$-I,4-glucan exo-hydrolase component of the enzyme complex, and its limited activity was probably restricted to the amorphous regions of the cellulose molecule. Acid-swollen cellulose, on the other hand, appeared to be open to attack by both $\beta$-I,4-glucan endo-hydrolase and exo-hydrolase components of the enzyme complex, giving rise to both glucose and cellobiose. 


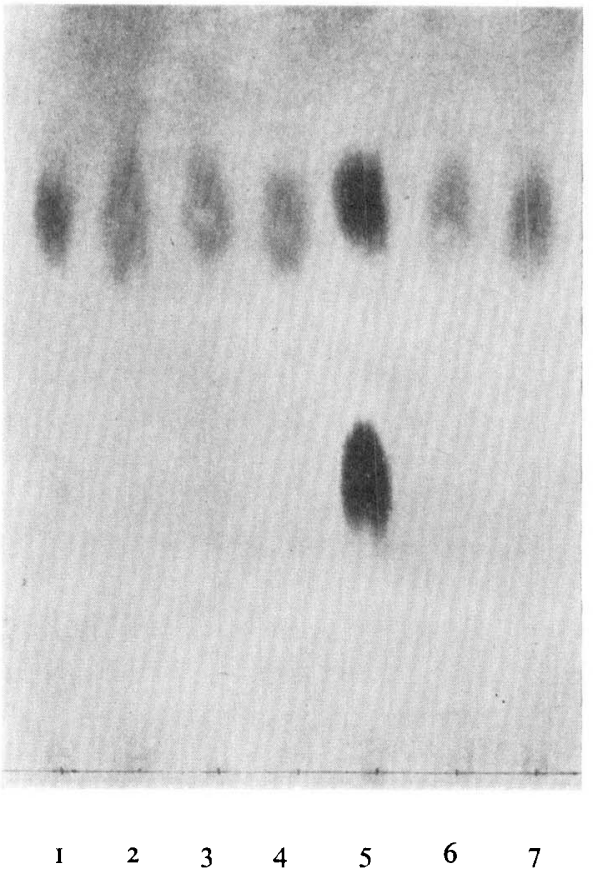

Fig. I

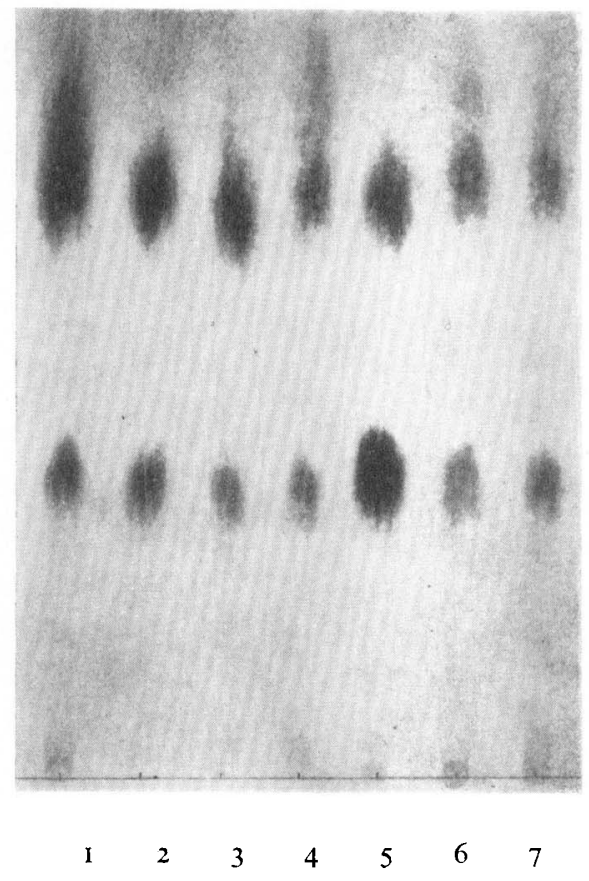

Fig. 2

Fig. 1. Hydrolysis of unmodified cellulose by Mucor pusillus and M. miehei. 1. M. pusillus Pcc410; 2. M. pusillus Cooney \& Emerson (strain 6); 3. M. pusillus Cooney \& Emerson (strain 8); 4. M. miehei NRRL2543; 5. glucose (G) and cellobiose (CB) standards; 6. M. miehei NRRL3I69; 7. $M$. miehei Cooney \& Emerson. Incubation time: $72 \mathrm{~h}$; reagent: triphenyltetrazolium chloride.

Fig. 2. Hydrolysis of acid-swollen cellulose by Mucor pusillus and M. miehei. I. .I. pusillus PCC4IO; 2. M. pusillus Cooney \& Emmerson (strain 6); 3. M. pusillus Cooney \& Emerson (strain 8); 4. M. miehei NRRL2543; 5. glucose (G) and cellobiose (CB) standards; 6. M. miehei NRRL3I69; 7. M. miehei Cooney \& Emerson. Incubation time: $48 \mathrm{~h}$; reagent: triphenyltetrazolium chloride.

\section{Growth and cellulase production in chemically defined media}

Mucor pusillus PCC4IO and M. miehei NRRL3I69 were cultivated in a chemically defined medium (Gordon, Stewart \& Clark-Walker, 1971) in which either the carboxymethylcellulose preparation $\mathrm{CMC}_{4} \mathrm{HIF}(0 \cdot 25 \%$, w/v) or glucose $(2 \%, \mathrm{w} / \mathrm{v})$ was incorporated as the sole carbon source. After 7 days of incubation at $37^{\circ} \mathrm{C}$, good growth was observed in both types of medium. Cellulase activity of mycelium-free filtrates was measured with $\mathrm{CMC} 4 \mathrm{HIF}$ as the substrate. With glucose as the carbon source, cellulase activity was not measurable in the filtrates; however, filtrates of both cultures grown in $\mathrm{CMC}_{4} \mathrm{HIF}$ containing medium displayed cellulase activity, averaging $\mathrm{I} \cdot 8$ enzyme units $/ \mathrm{mg}$ protein.

\section{DISCUSSION}

The evidence presented here supports the suggestion (Somkuti et al. 1969) that thermophilic species of Mucor possess the capacity to hydrolyse cellulose and its derivatives. The inducibility of the enzyme complex in Mucor miehei and M.pusillus was demonstrated by their failure to synthesize cellulase in a defined medium with glucose as the carbon source. 
These observations are at variance with those of Chang (1967), Eggins \& Malik (1969), Fergus (1969), and Tansey (1971). However, as a rule these investigators employed the most resistant forms of cellulose in their selective media and enzyme assays. Methods such as the measurement of the depth of clearing in cellulose-agar tubes (Tansey, 1971) or the disruption of filter paper, are simply not sensitive enough to detect the activity of culture filtrates of weakly cellulolytic organisms. The selective medium employed by Fergus (1969) included, in addition to a cellulose derivative (CMC), components such as urea that on their own may serve as the source of carbon for Mucor pusillus (G. A. Somkuti, unpublished observations). Therefore the repression of cellulase synthesis under such conditions is to be expected.

We do not suggest that either Mucor pusillus or $M$. miehei plays a primary role in the degradation of cellulose in nature; the experimental data indicate that not one component of the enzyme complex of these fungi would qualify as the so-called $\mathrm{C}_{1}$ component of a cellulase complex as defined by King \& Vessal (I969) that is necessary for the solubilization of native cellulose. However, it is known that the $\mathrm{C}_{1}$ component, when freed from the $\beta$-I,4-glucan glucanohydrolases of the cellulase complex, is practically without activity; this indicates a strong synergistic action on cellulose between the two types of enzyme components. Furthermore, cross-synergism between the $C_{1}$ and $\beta$-I,4-glucan glucanohydrolase components of the cellulase complexes of different fungi has also been demonstrated (Selby, 1969). Thus, the possibility cannot be excluded that both M.pusillus and $M$. miehei contribute to the degradation of cellulosic materials in nature, by virtue of cross-synergism between their own $\beta$-I,4-glucan glucanohydrolases and the $\mathrm{C}_{1}$ components of the cellulase complexes of other fungi.

The author thanks Professor H. Koffler for the use of his laboratory facilities.

\section{REFERENCES}

Bernfeld, P. (1955). Amylases, $\alpha$ and $\beta$. In Methods in Enzymology, vol. I, p. I 49. Edited by S. P. Colowick and N. O. Kaplan. New York: Academic Press.

Chang, Y. (1967). The fungi of wheat straw compost. II. Biochemical and physiological studies. Transactions of the British Mycological Society 5o, 667-677.

EgGins, H. O. WV. \& MALIK, K. A. (I969). The occurrence of thermophilic cellulolytic fungi in a pasture land soil. Antonie van Leeuwenhoek 35, 178-184.

Fergus, C. L. (1969). The cellulolytic activity of thermophilic fungi and actinomycetes. Mycologia 6r. I 20-I 29.

Gordon, P. A., Stewart, P. R. \& Clark-Walker, G. D. (1971). Fatty acid and sterol composition of Mucor generensis in relation to dimorphism and anaerobic growth. Journal of Bacteriology 1o7, II4I 20.

King, K. W. \& VessaL, M. I. (1969). Enzymes of the cellulase complex. In Cellulases and their Applications. Advances in Chemistry Series 95, p. 23. Edited by R. F. Gould. Washington: American Chemical Society.

Lowry, O. H., Rosebrough, N. J., Farr, A. L. \& Randall, R. J. (I95I). Protein measurement with the Folin phenol reagent. Journal of Biological Chemistry 193, 265-275.

Rész, A. (1968). Untersuchungen über den Mikroorganismenbesatz von belüftetem Heu. Zentralblatt fiir Bakteriologie, Parasitenkunde, Infektionskrankheiten und Hygiene (Abteilung II) 122, 597-634.

SELBY, K. (1969). The purification and properties of the $\mathrm{C}_{1}$-component of the cellulase complex. In Cellulases and their Applications. Advances in Chemistry Series 95, pp. 34-52. Edited by R. F. Gould. Washington: American Chemical Society.

Somkuti, G. A., Babel, F. J. \& Somkutr, A. C. (1969). Cellulolysis by Mucor pusillus. Applied Microbiology $17,888-892$. 
TANSEY, M. R. (197I). Agar-diffusion assay of cellulolytic ability of thermophilic fungi. Archiv fïr Mikrobiologie 77, I-I I.

Trevelyan, W. E., Procter, D. P. \& Harrison, J. S. (1950). Detection of sugars on paper chromatograms. Nature, London 166, 444-445.

WALSETH, C. S. (1952). Occurrence of cellulases in enzyme preparations from microorganisms. TAPPI 35 , 228-233. 